\title{
Integrated groundwater resource management in the peri-urban area of Banguntapan, Bantul
}

\author{
Ignasius Loyola Setyawan Purnama ${ }^{1 *}$, Sekar Dinul Salamah ${ }^{1}$, Kartika Ayu Wandari ${ }^{1}$, and Vincentia Anindha \\ Primacintya $^{2}$ \\ ${ }^{1}$ Faculty of Geography, Universitas Gadjah Mada, Yogyakarta, Indonesia \\ ${ }^{2}$ Accounting Programme, Master of Science and Doctoral, Faculty of Economics and Business, Universitas Gadjah Mada, Indonesia
}

\begin{abstract}
Banguntapan District in Bantul Regency is one of the peri-urban areas in the Special Region of Yogyakarta. The peri-urban area is an area located between the urban (Jogja City) and the rural (Bantul Regency). As a result of this strategic location, the development of this district is very rapidly marked by the growth of settlements, which in turn further requires water for housing purposes. The purpose of this research is to formulate an integrated water resources management model in the study area. To achieve this goal dynamic modeling is used. The model obtained was then simulated using the Powersim $2.5 \mathrm{c}$ computer program. Management efforts that can be carried out in this district are reducing groundwater use through saving water use and increasing water use from local water companies. Simulation results show that the combination of these two methods will slow down the time the safe yield will be exceeded, from 2039 to 2049.
\end{abstract}

\section{Introduction}

Water is one of the important natural resources for humans and other living things on earth. Without water, there might not be life on this earth. Problems arise when precisely with the advancement of civilization problems relating to water are also increasing. Flooding, drought and water pollution are some of the problems that often occur. It is expected that the availability of water resources in accordance with the demand and requirements is sufficient in quantity, both in quality and always available at all times.

Groundwater is one of the most important forms of water resources [1]. Even according to [2], groundwater is also one of the natural resources that plays a very important role in supporting human health, economic growth and biodiversity. However, the availability of groundwater is unlimited, because it is controlled by the geological conditions of an area [3, 4].

According to [5], the increase in groundwater demand is in line with population growth, expansion of agricultural land and industrial development. On the other hand, according to [6], an increase in groundwater extraction to meet the increasing demand of residents in urban areas causes a decrease in groundwater levels in big cities. In fact, according to [7], increasing population, increasing water use, water transfer between watersheds in one groundwater basin and the impact of global climate change can cause changes in groundwater level which in the long run will cause land subsidence $[8,9]$.

Because located in the peri-urban area of Yogyakarta City, Banguntapan District is one of the districts in
Bantul Regency that is experiencing rapid development, as indicated by the increasing population and settlement development. This district has an area of $28.48 \mathrm{~km}^{2}$ and is administratively divided into 8 villages namely Banguntapan, Baturetno, Singosaren, Jagalan, Tamanan, Wirokerten, Potorono and Jambidan. With a population of 145956 people in 2018, the population density is 5124 people $\mathrm{km}^{2}$, with a population growth rate of around $2.44 \%$. The impact of this population increase is the increasing number of water demand, while on the other hand the water recharge is reduced due to the increasingly narrow catchment area.

One effort that can be done to address these problems early is to develop a management model. One model that can be used is a dynamic model system [10], while the simulation can be done using Powersim. In the simulation, Powersim can be considered as a mini laboratory to experiment several alternative water management policies in an integrated manner before they are applied to the real world.

\section{Method of research}

The formulation of integrated water resources management in the study area uses dynamic modeling. The initial stage of dynamic modeling is to process primary and secondary data that are related and considered important in influencing groundwater availability, such as population data, population growth rate, rainfall, air temperature, runoff coefficient, aquifer thickness, specific yield and groundwater fluctuations [11]. Population and population growth affect the

\footnotetext{
* Corresponding author: Setyapurna@geo.ugm.ac.id
} 
amount of groundwater used, while rainfall, air temperature and runoff coefficient, play a role in determining groundwater supply. Groundwater fluctuations, aquifer thickness and specific yields will determine groundwater volume and the safe yield of its use. The secondary data is used to determine the rate of change in groundwater quantity from year to year. The model obtained was then simulated using the Powersim 2.5c computer program [12].

\section{Result and discussion}

\subsection{Determination of rain volume}

The amount of rain in Banguntapan District was determined based on the recording of rain at Gandok Station. Based on the recording at the station, it is known that the amount of annual rainfall in the District of Banguntapan is $2,461 \mathrm{~mm} /$ year. With an area of 28.48 $\mathrm{km}^{2}$, the rain volume is $70,089,280 \mathrm{~m}^{3} /$ year.

\subsection{Evapotranspiration calculation}

Potential evapotranspiration in the study area is calculated by the Tornthwaite Method which requires air temperature data. Based on data from the Central Statistics Agency of Bantul Regency, the average temperature in the Banguntapan District is $26.7^{\circ} \mathrm{C}$, so the calculation is as follows:

$$
\begin{gathered}
\operatorname{Epx}=16\left(\frac{10 \mathrm{~T}}{\mathrm{I}}\right)^{\mathrm{a}} \\
\mathrm{Epx}=16\left(\frac{10 \times 26.7}{151.59}\right)^{3.79} \\
\mathrm{Epx}=136.73 \mathrm{~mm} / \mathrm{month}
\end{gathered}
$$

Because Banguntapan District is located at latitude $7^{\circ} 49^{\prime} 29$ "LS, it refers to the table of mean possible duration of sun light in the Northern and Southern hemispheres expressed in units of 30 days of 12 hours each, the factor $\mathrm{f}$ is 1.0222416663 so $\mathrm{Ep}=$ $1,0222416663 \times 136.73=139.79 \mathrm{~mm}$ month. Based on the records at Gandok Station, only in January, February, March, November and December the rainfall exceeds the potential evapotranspiration value, so that only the five months are used to determine the actual evapotranspiration value during the year. With an area of $28.48 \mathrm{~km}^{2}$, the actual evapotranspiration volume in the study area is $19,906,096 \mathrm{~m}^{3}$ /year

\subsection{Calculation of groundwater volume}

Groundwater volume is calculated based on the assumption of static groundwater flow, which is the multiplication between aquifer thickness, wide area and specific yield. With a $35 \mathrm{~m}$ thick aquifer, a wide area of $28.48 \mathrm{~km}^{2}$ and a specific yield of 0.28 , the groundwater volume in the Banguntapan District is 279,004,000 $\mathrm{m}^{3} /$ year.

\subsection{Calculation of groundwater recharge}

Land use in Banguntapan District is dominated by settlements and agricultural land (Figure 1). Referring to the research of [13], the runoff coefficient in Banguntapan District is 0.648 . With a rain volume of $70,089,280 \mathrm{~m}^{3} /$ year, the runoff volume that occurs is $45,417,853 \mathrm{~m}^{3} /$ year. With the concept of water balance, groundwater recharge in the study area is determined by reducing the volume of rainfall with runoff volume and actual evapotranspiration volume of $70,089,280 \mathrm{~m}^{3} /$ year - 45,417,853 $\mathrm{m}^{3} /$ year $-19,906,096 \mathrm{~m}^{3} /$ year $=4,765,331$ $\mathrm{m}^{3} /$ year

Beside from rainwater, groundwater recharge in Banguntapan District also sources from the upper aquifer inflow from the Merapi Volcan Aquifer System. Referring to the calculation of [14], the inflow debit entering the District of Banguntapan is $19,785 \mathrm{~m}^{3} /$ day or $7,221,525 \mathrm{~m}^{3} /$ year.

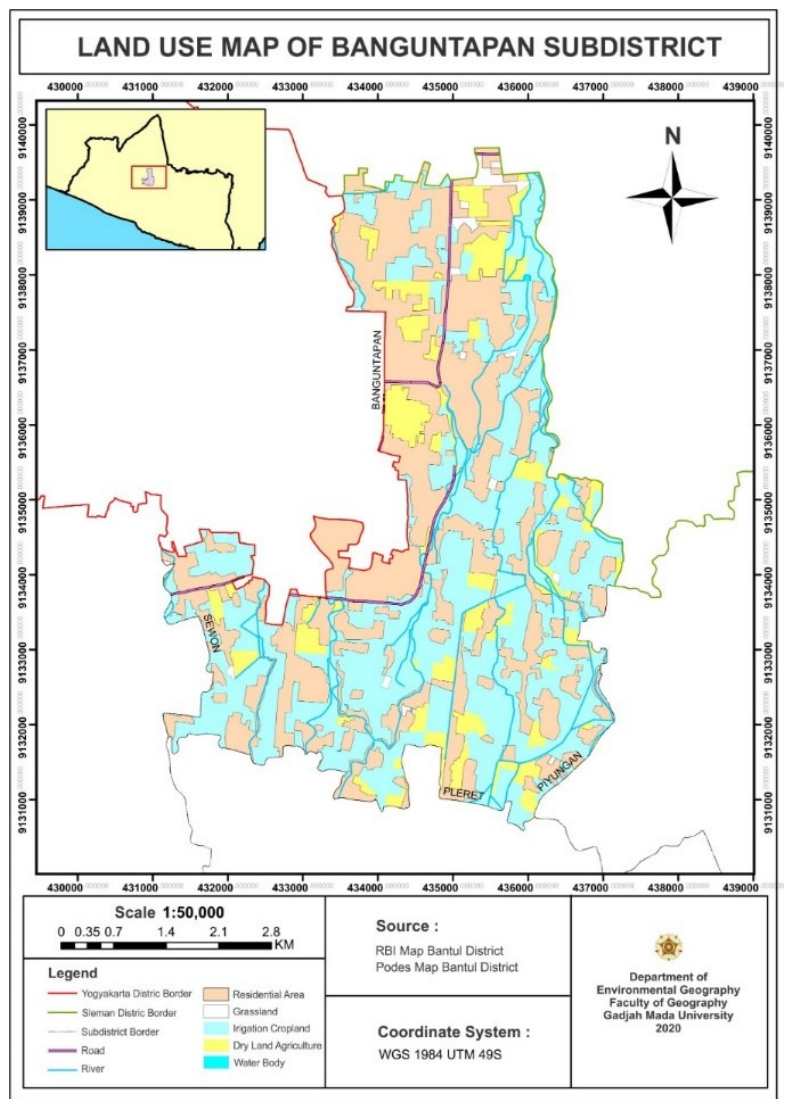

Fig. 1. Land use in Banguntapan District

\subsection{Determination of population increase}

Determination of the percentage of population growth refers to the data from Bantul in Numbers (2019). Based on the data in the report, the percentage of population growth in Banguntapan District in the period 2010-2018 was $2.44 \%$.

\subsection{Determination of water demand}

In this study, the calculated water demand are water demand for domestic demand which are determined according to the size of the population and the number 
of water demand per capita per day. Because Banguntapan District is located in the peri-urban area, referring to the results of a survey from the Directorate of Water Supply Development, the Directorate General of Human Settlements, the Ministry of Public Works and Public Housing, the water demand are determined to be 150 liters/person/day or $58.75 \mathrm{~m}^{3} /$ year.

\subsection{Determination of safe yield}

Groundwater safe yield for use are the result of multiplication between groundwater fluctuations $(\mathrm{F})$, area wide (A) and specific yield (Sy). With an average groundwater fluctuation of $1.64 \mathrm{~m} /$ year, an area wide of $28.48 \mathrm{~km}^{2}$ and a specific yield of 0.28 , the safe yield of groundwater use in the District of Banguntapan is $13,078,016 \mathrm{~m}^{3} /$ year.

\subsection{Groundwater management}

Conceptually, the groundwater management unit should be the groundwater basin, in this case the Yogyakarta groundwater basin. For this reason, in the discussion of groundwater management in Banguntapan District, only consider aspects that can be done in this region as its contribution to overall groundwater management in groundwater basins. Based on this concept, the groundwater management model in Banguntapan District is shown in Figure 2, while the calculation results are visualized in graphical form as shown in Figure 3.

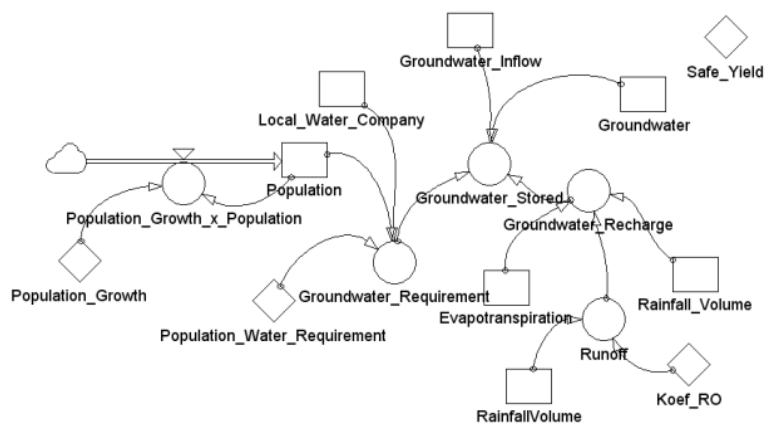

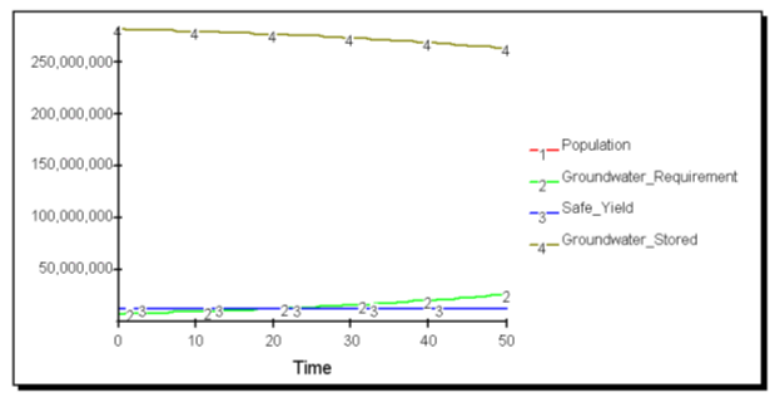

Fig. 3. Water demand, safe yield and groundwater stored

Noting Figure 3, it appears that in 2018 the population of Banguntapan Sub-district is 145,956 people. Assuming the percentage of the population growth rate is fixed, then in the 2068, it will reach 487,192 people or more than three times the population at this time. In 2068, there will be an increase in water demand from $7,991,091 \mathrm{~m}^{3} /$ year to $26,615,773 \mathrm{~m}^{3} /$ year.

The safe yield value of groundwater use in this region is $13,078,016 \mathrm{~m}^{3} /$ year, so that because the water demand is $13,199,658 \mathrm{~m}^{3} /$ year, by the 2039 water demand will have exceeded the safe yield. As a result, there will be a decrease in groundwater stored from $283,057,772 \mathrm{~m}^{3}$ to $264,375,082 \mathrm{~m}^{3}$ (Table 1 ).

\subsubsection{Groundwater management by water saving}

What can be done to reduce the amount of groundwater utilization for domestic needs by reducing the use of water per person per day from 150 liters/day to 120 liters per day (medium city standard). Noting Table 1 and Figure 4, it is known that by reducing water use, there is a phenomenon of a very significant decrease in water demand. If previously in 2039 the population's water needs of $13,199,658 \mathrm{~m}^{3} /$ year had exceeded the safe yield, with a reduction in water use would only reach $10,548,125 \mathrm{~m}^{3} /$ year $\mathrm{m}^{3} /$ year which had not exceeded the safe yield. With this water saving effort, the groundwater requirements will exceed safe yields in 2048.

Fig. 2. Groundwater management model in Banguntapan

Table 1. Groundwater management scenarios and their impact on groundwater usage

\begin{tabular}{|r|r|r|r|r|}
\hline \multicolumn{1}{|c|}{ Year } & $\begin{array}{c}\text { Groundwater Usage Without } \\
\text { Management }\left(\mathrm{m}^{3} / \text { year }\right)\end{array}$ & $\begin{array}{c}\text { Water Saving } \\
\left(\mathrm{m}^{3} / \text { year }\right)\end{array}$ & $\begin{array}{c}\text { LWC increasement } \\
\left(\mathrm{m}^{3} / \text { year }\right)\end{array}$ & $\begin{array}{r}\text { Water Saving and LWC } \\
\text { Increasement }\left(\mathrm{m}^{3} / \text { year }\right)\end{array}$ \\
\hline 2018 & $7,933,084$ & $6,334,866$ & $7,875,077$ & $6,276,857$ \\
\hline 2019 & $8,128,067$ & $6,490,852$ & $8,070,060$ & $6,432.845$ \\
\hline 2020 & $8,327,807$ & $6,650,644$ & $8,269,799$ & $6,592,637$ \\
\hline 2021 & $8,532,421$ & $6,814,335$ & $8,474,414$ & $6,924,013$ \\
\hline 2022 & $8,742,027$ & $6,982,021$ & $8,684,020$ & $7,095,790$ \\
\hline 2023 & $8,956,748$ & $7,153,797$ & $8,898,741$ & $7,271,758$ \\
\hline 2024 & $9,176,708$ & $7,329,765$ & $9,118,701$ & $7,452,020$ \\
\hline 2025 & $9,402,035$ & $7,510,027$ & $9,344,028$ & $7,636,680$ \\
\hline 2026 & $9,632,860$ & $7,694,687$ & $9,574,853$ & $8,019,627$ \\
\hline 2027 & $9,869,317$ & $7,883,852$ & $9,811,310$ & $8,218,136$ \\
\hline 2028 & $10,111,544$ & $8,077,634$ & $10,053,537$ & $8,421,490$ \\
\hline 2029 & $10,359,681$ & $8,276,143$ & $10,301,674$ & $8,629,805$ \\
\hline 2030 & $10,613,872$ & $8,479,497$ & $10,555,865$ & \\
\hline 2031 & $10,874,267$ & $8,687,812$ & $10,816,259$ & \\
\hline 2032 & $11,141,014$ & $8,901,210$ & $11,083,007$ & \\
\hline
\end{tabular}




\begin{tabular}{|r|r|r|r|r|}
\hline \multicolumn{1}{|c|}{ Year } & $\begin{array}{c}\text { Groundwater Usage Without } \\
\text { Management }\left(\mathrm{m}^{3} / \text { year }\right)\end{array}$ & $\begin{array}{c}\text { Water Saving } \\
\left(\mathrm{m}^{3} / \text { year }\right)\end{array}$ & $\begin{array}{c}\text { LWC increasement } \\
\left(\mathrm{m}^{3} / \text { year }\right)\end{array}$ & $\begin{array}{c}\text { Water Saving and LWC } \\
\text { Increasement }\left(\mathrm{m}^{3} / \text { year }\right)\end{array}$ \\
\hline 2033 & $11,414,270$ & $9,119,815$ & $11,356,263$ & $9,061,808$ \\
\hline 2034 & $11,694,193$ & $9,343,753$ & $11,636,186$ & $9,285,746$ \\
\hline 2035 & $11,980,947$ & $9,573,156$ & $11,922,940$ & $9,515,149$ \\
\hline 2036 & $12,274,698$ & $9,808,157$ & $12,216,691$ & $9,750,150$ \\
\hline 2037 & $12,575,616$ & $10,048,891$ & $12,517,609$ & $10,237,884$ \\
\hline 2038 & $12,883,876$ & $10,295,499$ & $12,825,869$ & $10,490,118$ \\
\hline 2039 & $13,199,658$ & $10,548,125$ & $13,141,651$ & $10,748,907$ \\
\hline 2040 & $13,523,145$ & $10,806,915$ & $13,465,138$ & $11,014,012$ \\
\hline 2041 & $13,854,526$ & $11,072,019$ & $13,796,518$ & $11,563,584$ \\
\hline 2042 & $14,193,991$ & $11,343,592$ & $14,135,984$ & $11,848,770$ \\
\hline 2043 & $14,541,740$ & $11,621,790$ & $14,483,733$ & $12,140,711$ \\
\hline 2044 & $14,897,973$ & $11,906,777$ & $14,839,966$ & $12,439,775$ \\
\hline 2045 & $15,262,899$ & $12,198,718$ & $15,204,892$ & $12,746,136$ \\
\hline 2046 & $15,636,730$ & $12,497,782$ & $15,578,722$ & $13,059.973$ \\
\hline 2047 & $16,019,681$ & $12,804,143$ & $15,961,674$ & $13,381,467$ \\
\hline 2048 & $16,411,977$ & $13,117,980$ & $16,353,970$ & $13,710,805$ \\
\hline 2049 & $16,813,844$ & $13,439,474$ & $16,755,837$ & $17,167,510$ \\
\hline 2050 & $17,225,517$ & $13,768,813$ & &
\end{tabular}

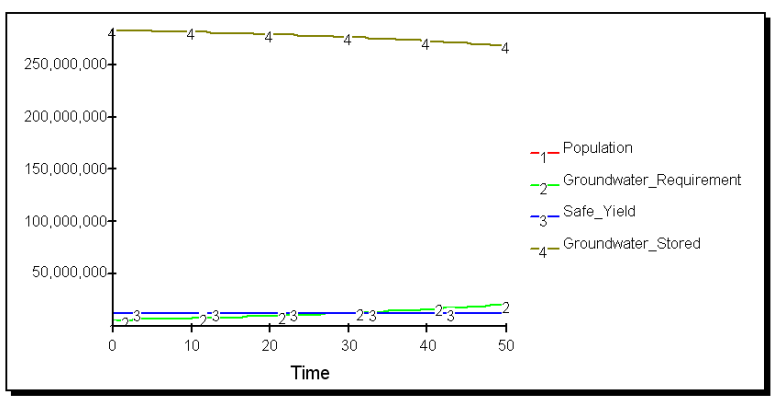

Fig. 4. Decreasing of water demand through savings

\subsubsection{Increasing Water Use from Local Water Companies}

The basic concept of this conservation method is that if a large proportion of the population uses water from the Local Water Companies (LWC), groundwater exploitation will be reduced. For this reason, it is assumed that the use of water from the Local Water Company has doubled, from $55,007 \mathrm{~m}^{3} /$ year to $110,014 \mathrm{~m}^{3} /$ year. The simulation results show that the doubling of LWC water production does not significantly influence the availability of groundwater in the study area. Safe yield of groundwater use will still occur in 2039 (Table 1 and Figure 5).



Fig. 5. Decreasing water demand through the increasement usage of LWC

\subsubsection{Groundwater Management by Saving Water and Increasing LWC Production}

In this alternative groundwater management model, the parameter for the amount of water used for domestic demand is reduced and the use of water from the Local Water Company is increased.

The simulation results show that there is indeed a decrease in water demand, but the decrease is almost similar to water saving. This combination of two methods will indeed slow down the time for exceeding safe results, from 2048 to 2049 (Table 1 and Figure 6).

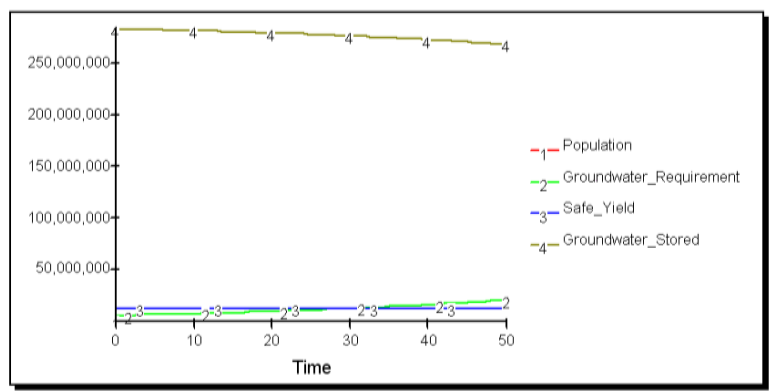

Fig. 6. Decreasing of water demand through saving water use and increasing the use of water from Local Water Company (LWC).

\section{Conclusion}

Groundwater management in Banguntapan District cannot be separated from overall groundwater management in the Yogyakarta Groundwater Basin. Nevertheless, partial management in this district can also be done to contribute to the overall management of groundwater in this area. Based on this, the management effort that can be done in this district is to reduce the use of groundwater through saving water use and increasing water use from local water companies (LWC). Simulation results show that the combination of these 
two methods will slow down the time the safe yield will be exceeded, from 2039 to 2049 .

This article is the result of a study financed by the Universitas Gadjah Mada 2020 Final Assignment Recognition (Rekognisi Tugas Akhir/RTA) Programme Fiscal Year 2020.

\section{References}

1. S.A. Naghibi, H.A. Pourghasemi, Environ Monit Asses 188,44:1-25(2015).

2. M.L. Waikar, A.P. Nilawar, International Journal of Innovative Research in Science Engineering and Technology 3,5:12163-12174(2014).

3. K.R. Rushton, Groundwater Hydrology: Conceptual and Computational Models. John Wiley \& Sons Ltd, The Atrium, Southern Gate, Chichester, West Sussex (2003).

4. T. Kumar, A.K. Gautam, D.C. Jhariya, Environ Earth Sci 75,649:1-16(2016).

5. A.S. Jasroti, B.D. Bhagat, A. Kumar, R. Kumar, J Indian Soc Remote Sens., 41,3:365-377(2012).

6. V.Y. Tam, T.T.V. Nga, Journal of Environmental Management 227:107-116(2018).

7. F.D. Tillman, S.A. Leake, Hydrogeol. J. 18: 15151524(2010).

8. K.-P. Seiler, J.R. Gat, Groundwater Recharge from Run-Off. Infiltration and Percolation. Springer, The Netherlands (Chapter 6) (2007).

9. Q.H. Deng, R.M. Yuan, B.K. Yao, J. Chin. Univ. Min. Technol. 17,1:0085-0089(2007).

10. A. Ford, Modeling of Environment: An Introduction to System Dynamics Models of Environmental System. Island Press, California (1999).

11. Purnama. IOP Conf. Series: Earth and Environmental Science 451: 012085(2020).

12. H. Arne, H. Byrkness, J. Cover, Quick Tours in Powersim. Powersim Press, Virginia (2005).

13. A. Galis, B. Widodo, W. Dhandhun, R. Suphia, M.P. Yosi, R.I. Faris, Analisis perubahan koefisien aliran permukaan melalui GIS (studi kasus : sub DAS Gajah Wong, Yogyakarta tahun 2008 dan 2016) (2016). [in Bahasa Indonesia].

14. Purnama, S., Suyono, B. Sulaswono, Forum Geografi 22,2:111-122 (2007). [in Bahasa Indonesia]. 